\title{
Diversity of Internal Governance and Financial Reporting Quality: Post-GFC of an Emerging Market
}

\author{
Anuar Sarun, Nooraisah Katmon, Anis Suriati Ahmad, Zam Zuriyati Mohamed
}

\begin{abstract}
We examine whether wide-ranging board diversity reduce earnings management from the emerging market of Malaysia. We contribute to the prior literature in several ways. First, while previous literature are mainly focusing on the developing economy, our study is the first that examine the relationship between all-inclusive set of diverse board characteristics and earnings management from the emerging economy. Second, we concentrate to the post-GFC period, where we intentionally avoid the GFC, a situation where managerial opportunistic behaviour to engage in earnings management is more prevalent due to economic reason. Third, we cover the potential complementary or substitutive effects of board diversity characteristics on earnings management. Using 1400 listed firms in emerging market of Malaysia over the period of 2009-2015, in contrast to our prediction, our findings demonstrated that the relationship between board diversity characteristics and earnings management in the Malaysia is mixed. We therefore conclude that the diversity mechanism that work well in the developing countries might not necessarily compatible to the emerging economy such as Malaysia.
\end{abstract}

Keywords: Board Diversity, Corporate Internal Governance, Financial Reporting Quality

\section{INTRODUCTION}

We investigate the relationship between wide-ranging dimension of board diversity characteristics and earnings management by listed firms in Malaysia during the year 2009-2015. We define earnings management following Healy and Wahlen $(1999$, p. 368) “... as the situation where managers used deliberation to modify the accounting figures within the boundary of accounting standard in order to mask firms' true performance with an intention to mislead the users or to influence contractual outcome that depends on reported earnings.

Revised Manuscript Received on June 22, 2019.

Anuar Sarun, Faculty of Management and Economics, Universiti Pendidikan Sultan Idris (UPSI)

Nooraisah Katmon, Faculty of Management and Economics, Universiti Pendidikan Sultan Idris (UPSI)

Anis Suriati Ahmad, Faculty of Management and Economics, Universiti Pendidikan Sultan Idris (UPSI)

Zam Zuriyati Mohamed, Faculty of Business and Finance, Universiti Tunku Abdul Rahman (UTAR)
We exploit Malaysian environment in our study given that Malaysia is one of the emerging market that have encourage diversity policy among listed firms through the "Letter" released by Bursa Malaysia on $22^{\text {nd }}$ July 2014 which stipulated that listed firms are required to disclose an information related to diversity policy on gender, age as well as ethnicity, while at the same time is having higher level of corruption when compared to other developed countries. Given that there is an association between high level of corruption and earnings management according to the prior literature (Pappas, Leventis, \& Owusu-Ansah, 2011), we posit that the impact of board diversity on earnings management in emerging economy such as Malaysia might is unclear when compared to the developed economies counterparts. Our study therefore intend to fill the void in the literature by examining the impact of diversity of board and earnings management from the developing countries viewpoint.

We manipulate the post-GFC period given that it is a relevant setting for us to understand the impact of whether diverse board reduce manager's inclination to manage earnings. We intentionally avoid the GFC since we acknowledge that manager's is more prevalent to manipulate earnings during economic turmoil due to bad economic situation that can be describe as high bad debt, more obsolete inventory as well as sales drop (Dechow \& Schrand, 2004). We therefore intend to examine the effectiveness of diverse board on earnings management in a relevant setting - where the economics is more stable and diversity is promoted in the Malaysian setting. We elude our study from the pre-GFC setting given that during that time diversity of board is not well practices by the firms and not yet recommended by Bursa Malaysia.

Malaysia is a relevant subject to study the impact of board diversity and earnings management due to following reason. First, diversity of board has becoming one of the main agenda by the regulators, despite of the facts that the benefit of diversity is ambiguous in this country. Second, Malaysia is sharing similar pessimistic characteristics as any other emerging economy (Katmon et al. 2017) where the institutional setting has been viewed as less efficient as represented by high corruption level (Transparency International, 2015), inequitable income distribution (World Bank, 2016) and lower investors protection (La Porta, Lopez de Silanes, Shleifer, \& Vishny, 2000). 
Therefore, while diverse board is relevant in reducing earnings management in develop country (e.g., Arun, Almahrog, \& Ali Aribi, 2015a), it is unclear whether board diversity mechanism are able to work similarly in Malaysia, where the ethical principles, governance and regulation is differ (Katmon et al. 2017). To be specific, high corruption level in emerging economy such as Malaysia (Transparency International, 2015) might justify opportunistic earnings management behaviour in Malaysian firms.

Studies have demonstrated several unintended consequences of board diversity. The expensive cost of acquisition of the foreign board members (Knyazeva, Knyazeva, \& Masulis, 2013)(Hahn \& Lasfer, 2016) and communication breakdown (Miletkov, Poulsen, \& Wintoki, 2014) eventually affect firms governance effectiveness.

A study on diversity of internal governance of firms and earnings management is important due to several reason. First, Malaysia has move forward in internal governance diversity by allocating $30 \%$ quota for female directors in the board starting the year 2016. Therefore, this present study will be useful for the policymakers in Malaysia in understanding the impact of internal governance diversity on firm's disclosure transparency. Second, while changing or restructuring the governance structure in a company is very costly (e.g., cost of appointing new directors, recruiting process, nomination process, etc), it is important to note that we are still unclear whether the implementation of internal governance diversity is beneficial to the firms, especially in curbing earnings management practices, where it act as a benchmark of transparency of firms disclosure policy that will be useful in understanding the operation activities and in determining the value of the firms and the share price. Moreover, Malaysia is unique in the sense it has different environmental context in respect to politics, social, religion and culture, compared to other western country, as well as other countries in emerging economy (Katmon et al. 2017b). In this regards, it is important for us to identify whether diversity in Malaysia is valuable in reducing earnings management. Third, our study uses four proxies for earnings management namely discretionary accruals, accrual estimation error and the tendency of reporting a profit rather than a loss. Fourth, while previous study mainly focused on one or two types of diversity, we extend prior literature by examining the diversity of board and audit committee from broader spectrum including gender, education level, education background, age, ethnicity, tenure and nationality. Finally, our study also complement previous research by examining the complementary effect or substitutive effects of diversity gamut. This is crucial, given that governance mechanism are interrelated each other. Therefore, in the case that diversity elements are complementary, this suggest that firms should adhere only to certain types of diversity, hence it will reduce the cost of governance in the firms. Given that the governance structure is basically very costly to the firm (Gruning, 2010), it is expected that the findings will be helpful for the policymakers in Malaysia in setting the regulation related to diversity of the board in Malaysia.

We outlined our paper as follows. In the second section, we discuss the theoretical and empirical literature. In the third section, we describe our sample, data and model. We

present and discuss our findings in the fourth section. In the last section, that is section five, we conclude our paper.

\section{LITERATURE REVIEW}

The cornerstone of agency theory lies in the principalagent relationship where the agents are entrusted to make decision on behalf of the principal (Jensen \& Meckling, 1976). Earnings management is one form of agency cost that incurred due to misalignment of interest between agent and principal as manifested from the agency problems - conflict of interest and information asymmetry (Davidson et al. 2004, p. 267). In this instance, sound governance practices in the firm is expected to be able to curb agency cost (i.e., earnings management practices) (Holm \& Scholer, 2010)(Cormier \& Martinez, 2006). Agency theory suggests that diversity in the boardroom may strengthen the existing control mechanisms over executives and managers and influence the management decision on information disclosure (Husillos \& Alvarez, 2008). From the agency theory perspective, it can be argued that a diverse board is more likely to be vigilant for agency problems simply because a greater number of people will be reviewing management actions (Fauzi \& Locke, 2012). Board diversity also may increase board independence to establish better control and monitor mechanism because of the assumption that an individual tends to be control-oriented, economical and rational; however, a diverse board may contribute different styles of controlling and monitoring to the management (Prihatiningtias, 2012).

The importance of board diversity can also be argued from the theoretical perspective including agency theory (Anila, 2014; Carter, D’Souza, Simkins, \& Simpson, 2010) and resource dependence theory (Bear, Rahman \& Post, 2010; Carter, D’Souza, Simkins \& Simpson, 2010; Post, Rahman \& Rubow, 2011). According to agency theory, directors as agents of the firm may be motivated to voluntarily disclose more of the firm's activities to reduce information asymmetry (Gul \& Leung, 2004). Boards are perceived as mechanisms to overcome the separation of ownership and management which give rise to self-serving utility maximization by the company managers (Anila, 2014). Since the board's obligation is to ensure that management prioritizes the interest of shareholders, agency theory has suggested that a more diverse board monitors managers better because board diversity increases board independence (Carter et al., 2010). Diversity in board will indicate different approaches taken by the director in disclosing the information needed as they have different expertise and communication styles. In addition, agency theory underlines the idea that a more diverse board may improve performance (Alvarado, Briones \& de Fuentes Ruiz, 2011). On the other hand, the importance of board diversity can be justified from the resources dependence theory perspective. Pfeffer and Salancik (1978) view board members as resources of the tangible and intangible assets which are fundamental for firm performance and shape its behaviour and environment.

Published By: 
The theory suggest that the creation of valuable resources bring competitive advantage to companies as the board members and potential board members often present their experience, expertise and reputation that can benefit the firm. The selection of resources has an important implications in the role and structure of the board, because boards can be used as a mechanism to establish the corporation relationship with external environment whereby diverse boards bring more links and greater access to resources (Duztas, 2008). The creation of this important link is crucial because diverse directors have diverse opinions and non-traditional approaches to problems as they are less likely insiders or business experts (Carter et al., 2010). This argument can further be supported by Bathula (2008) who pointed that this theory underscores the importance of board as resource and envisages a role beyond their traditional control responsibility.

The upper echelons theory suggest that heterogeneity of board improves board cognitive base and bounded rationality in their decision making process (Hambrick \& Mason, 1984). Board decision is a reflection of the values, knowledge, skills, personal characteristics, educational background and capabilities of the board, thus every decision made by the board will be filtered through individuals value and cognitive base (Hambrick \& Mason, 1984). Given that board members carrying their "cognitive and emotional" experience with them (Hambrick\& Mason, 1984 , p. 2000) in their daily routine, including their workplace in their subconscious mind, we posit that all of these values potentially influence their decision making process to certain extent including decision on earnings management. The resource based view claim that firm's resources are valuable, rare, hard to imitate and not easily substitute - and these assets are important for firms to make strategic decision making that lead to sustainable competitive advantage (Barney, 2001). Firms resources definition is infinite and anything that can contribute to the weaknesses or strength can be considered as firms resources (Wernerfelt, 1984).

Previous literature suggest that anything that potentially increases the value of the firms can also destroy the value of the firms (Ansari \& Munir, 2008)(Bowman \& Ambrosini, 2003). This is because, the acquired resources might not able to perform its function effectively within firm's environment due to "poor management" standard (Bowman $\&$ Ambrosini, 2003) and other externalities. Therefore, from the theoretical perspective, it is important for us to refine the effectiveness of board diversity in curbing earnings management in developing country like Malaysia, where the governance and transparency standard are fall behind the developed countries counterparts.

Diverse board is expected to be able to reduce earnings management given that (i) it is hard for diverse board to collude in opportunistic behaviour (ii) managers from minority ethnics normally more sensitive about its impact to the minority stakeholders (iii) they have chance to ask their conscience since their values will tell them what's right and what's not and (iv) they prefer to stand out in their principal because they don't feel that they (v) they tend to be whistle blowers because in real case, majority of the whistle blowers are outsiders (e.g. Olympus, etc.).

A further issue in corporate governance literature is the role and duty of board of directors. The board of directors is the most important organ of the company who are responsible for the management of the company and the directors decide the strategy for the business operation (Aina, 2013). The board is also the most important internal control mechanism in corporate governance which is used to curb agency issues in the corporation (Lazzaretti, Godoi, Camilo, \& Marcon, 2013). Nevertheless, the impact of diversity on earnings management is unknown in developing countries. It is possible that different regulatory, business ethnics and cultural factors lead to unintended consequences of diversity of board.

From Malaysia perspective, no prior studies have specifically examine the relationship between diversity and earnings management. While previous Malaysian study concentrated on limited diversity of board characteristics on firm performance (Gul, Munir, \& Zhang, 2016; Abdullah, Ismail, \& Nachum, 2016), our Malaysian study complements prior literature in this area by examining the impact of broader spectrum of board diversity (i.e., gender, age, tenure, education level, education background, ethnicity and nationality) on earnings management.

Previous literature on board diversity and earnings management is limited and majority of studies on board diversity have been flocked on its impact on firm performance (Farag \& Mallin, 2017)(Abdullah et al., 2016)Gul et al., 2016) and CSR (Ben-Amar, Chang, \& McIlkenny, 2015)(Hafsi \& Turgut, 2013)(Boulouta, 2013). Our study thus fill the void by examining the impact of board diversity and earnings management from emerging economy of Malaysia.

Among studies on developed market, Arun, Almahrog, \& Ali Aribi (2015b)a UK study examine the relationship between female directors and earnings management. They found that female directors constrain earnings management in the UK firms. (Duong \& Evans, 2016)Australian study focus on CFO gender and composition on earnings management. Their result demonstrated that female CFO are less prone to manipulate earnings when compared to the male CFO counterparts. Troy, Smith, \& Domino(2011), a US study concentrated on the age, experience and educational background of board members that justify illegal fraud. They found that younger CEO, CEO without business degree and CEO with less functional experience are more prone to fraud compared to the older CEO, vast functional experience and CEO with business degree. Dauth, Pronobis, \& Schmid(2017), a German study on the internationalization of top management and earnings quality found that $\mathrm{CFO}$ internationalization (in respect to education and work experience) are associated with higher earnings quality using firm years of 109 firms during the year 20052010.

Peni \& Vähämaa(2010)a US study reported that the appointment of female $\mathrm{CFO}$ is associated with incomedecreasing discretionary accruals using 391 firms over the years 2003 to 2007 (i.e., 1955 firm-year observation). 
Their finding suggest that female CFO as more risk averse and more conservative in reporting earnings. (Luo, Xiang, \& Huang, 2017) China study demonstrated that the association between the presence of female directors in the board and real activities manipulation is negative using 1183 firmyears observation during 2000-2011.

We contend that previous study merely focusing on developed countries viewpoint such as Canada (Labelle et al., 2010); US (Krishnan \& Parsons, 2008)(Duong \& Evans, 2016)(Arun et al., 2015b) covering limited number of diversity proxies such as gender per se (Krishnan \& Parsons, 2008)(Peni \& Vähämaa, 2010) or internationalization perspective only (Dauth et al., 2017) and utilizing data preGFC (Krishnan \& Parsons, 2008; Labelle, Gargouri, \& Francoeur, 2010; Dauth, Pronobis, \& Schmid, 2017)). We argue that the findings from the previous study are not suitable for Malaysian context given that Malaysia is a developing countries where dissimilarity of institution is apparent when compared to developed nation, and myriad diversity perspective is necessary to examine due to multicultural and multiracial society in Malaysian context.

\section{RESEARCH METHODOLOGY}

\section{Sample \& Data}

Our sample comprise of 1400 listed firms in Bursa Malaysia from 2009 to 2015 . We intentionally focused on the year 2009 as our starting point in order to avoid GFC that occurs in 2008. Our study collect the data till the year 2015 given that in 2016, listed firms are required to allocate $30 \%$ position of female in the board. We select 200 firms each year using random sampling method. Following (Haniffa \& Cooke, 2005), we exclude financial firms due to different regulatory requirement that financial firms have to engage. Statistical analysis such as descriptive statistics, pairwise correlation and regression will be used to analyse the data.

\section{Measurement for Earnings Management}

We measure earnings management using (i) Dechow and Dichev (2012) model following McNichols (2002) (ii) Modifed Jones Model following Dechow et al. (1994) (iii) Performance-Adjusted Discretionary Accrual according to Kothari et al. (2008) and (iv) the tendency of reporting a profit rather than a loss (small profit) according to Francis et al. (2013). This is similar to (Peni \& Vähämaa, 2010) which using Dechow and Dichev and Modified Dechow and Dichev models in their study.

\section{Measurement for Diversity Variables}

We use coefficient of variation for the interval or continuous variables (i.e. age and tenure) (Ali et al. 2014; Fan 2012; Hafsi and Turgut 2013). ${ }^{1}$ We employ Blau's Index $(1977)^{2}$ to measure the categorical variable including

\footnotetext{
${ }^{1}$ This was computed using standard deviation divided by the mean (i.e. Coefficient of Variation $=\sigma / \mu$ ).

${ }^{2}$ A version of Blau (1997) index was originally proposed by Simpson (1949) as a measure of species diversity in an ecosystem and it is also known as Herfindahl's (1950) index and Hirschman's (1964) index when applied to the
}

gender, educational level, educational background, nationality and ethnicity in corroboration with previous studies in board diversity (Campbell and Mínguez-Vera 2008; Bear et al. 2010; Fodio and Oba 2012; Tibben 2010; Fan 2012). ${ }^{3}$

\section{Control Variables}

We include audit committee characteristics (e.g. audit committee size, audit committee expertise, audit committee meeting and audit committee independent) and board characteristics (e.g. board size, board meeting, board independent) in our model to capture for internal governance effect on earnings management. Several firm characteristics variables are also included in our regression namely firm size, leverage, profitability, total accrual, loss firms, and change in sales, industry types and year effects.

\section{Regression Model}

Our regression model is specified as below:

$E M=$ GENDER + EDULEVEL + EDUBGROUND + ETHNIC + AGE + NATION + TENURE + BODMEET + BODSIZE + BODIND + ACSIZE + $A C M E E T+A C I N D+S I Z E+L E V+P R O F I T+$ LOSS + NCF/LTA + PPE/LTA + TA/LTA + CHGEINSALES/LTA + INDUSTRY DUMMIES + YEAR DUMMIES + e

Where; measurement of industrial concentration (Campbell and Mínguez-Vera 2008).

${ }^{3}$ The Blau Index is calculated as follows; $\mathrm{BI}=1-\Sigma_{\mathrm{i}=1}^{\mathrm{n}} p_{\mathrm{i}}^{2}$. Where $p_{\mathrm{i}}$ is the proportion of board members in each category and $n$ is the total number of board members. The index indicates the extent of concentration of group members, ranging from high concentration in a single category, with index of 0 indicating complete homogeneity, to extremely low concentration or complete heterogeneity, with an index of 1. 


\begin{tabular}{|c|c|c|}
\hline$E M$ & $=$ & $\begin{array}{l}\text { Earnings management is measured using (i) Modified Jones Model (ii) } \\
\text { Performance Adjusted Discretionary Accrual (iii) Dechow\&Dichev Model } \\
\text { and (iv) Small profit }\end{array}$ \\
\hline GENDER & $=$ & Percentage of female on the board \\
\hline EDULEVEL & $=$ & $\begin{array}{l}\text { Education level measured by variation in educational qualification, namely } \\
\mathrm{PhD} \text {, master degree, undergraduate degree, diploma and others using Blau's } \\
\text { Index (1977) where } \mathrm{p} \text { is the proportion of board of directors in each category } \\
\text { of education level }\end{array}$ \\
\hline EDUBGROUND & $=$ & $\begin{array}{l}\text { Education background measured by variation in education background such } \\
\text { as accountancy, banking and finance, engineering, architecture, art, science, } \\
\text { business management, economics, law and others using Blau's Index (1977) } \\
\text { where p is the proportion of board of directors in each category of education } \\
\text { background }\end{array}$ \\
\hline ETHNIC & $=$ & $\begin{array}{l}\text { Measured by variation in ethnicity diversity (Malay, Chinese, Indian and } \\
\text { others) using Blau's index }\end{array}$ \\
\hline$A G E$ & $=$ & Age of board \& audit committee members \\
\hline TENURE & $=$ & $\begin{array}{l}\text { Measured by dispersion in tenure (years of services)of the board members } \\
\text { using coefficient of variation }\end{array}$ \\
\hline NATION & $=$ & $\begin{array}{l}\text { Board nationality diversity measured using the Blau Index the percentage of } \\
\text { foreign directors on the board }\end{array}$ \\
\hline BODMEET & $=$ & Number of board meeting in a year \\
\hline BODSIZE & $=$ & Number of members in the board \\
\hline BODIND & $=$ & Percentage of independent directors in the board \\
\hline ACMEET & $=$ & Number of audit committee meeting in a year. \\
\hline$A C S I Z E$ & $=$ & Number of audit committee members \\
\hline$A C I N D$ & $=$ & Percentage of independent directors in the audit committee \\
\hline SIZE & $=$ & Natural log of total assets \\
\hline$N C F / L T A$ & $=$ & Net cash flow from operation divided with lagged total assets \\
\hline$P P E / L T A$ & $=$ & Gross property, plant and equipment divided with lagged total assets \\
\hline TA/LTA & $=$ & \\
\hline CHGEINSALES/LTA & $=$ & Change in sales divided with lagged total assets \\
\hline LOSS & $=$ & 1 if firms received negative profit that year, 0 otherwise \\
\hline PROFIT & $=$ & Net profit divided with total assets \\
\hline$L E V$ & $=$ & Total debt divided with total assets \\
\hline YEAR DUMMIES & $=$ & $\begin{array}{l}2009,2010,2011,2012,2013,2014 \text { dummies are included in the model. } \\
\text { Dummy for the year } 2015 \text { was excluded from the model. }\end{array}$ \\
\hline INDUSTRY DUMMIES & $=$ & \\
\hline$e$ & $=$ & Error Terms \\
\hline
\end{tabular}

\section{FINDINGS AND DISCUSSION}

\section{Descriptive Statistics}

We tabulate the descriptive statistics in Table 1 . As we can see from the Table 1, the mean for DD is 0.07604, within the range of 0.000725 and 0.51438 . In regards to MJONES, the mean is 0.22548 , and with the minimum value of 0.002013 and the maximum value of 2.6534 . We also noted that the mean for KOTHARI is 0.27366 , and its value scattered within the range of 0.00166 to 3.1948 . The mean for SP is 0.8242 .

In regards to board diversity variables, our mean for GENDER is 0.0897 with a range value of 0 to 0.014 . The mean for EDULEVEL is 0.5645 within the range of 0 to 0.958. For NATION, the average is 0.0737 with a range value of 0 to 0.71 . In regards to EDUBGROUND, the mean is 0.7243 , with the range between 0.19 and 0.911 . The average of ETHNIC, AGE and TENURE are 0.3843, 0.157 and 0.6048 respectively and they ranged from 0 to 0.77 , 0.062 to 0.283 and 0 to 1.69 respectively.
In respect to governance variables, the average number of BODSIZE is 7.4635 , with the range of 4 to 15 . The mean for BODIND is 0.458 which suggest that in average, listed firms in Malaysia have around $45.8 \%$ of independent directors in their board. The range of BODIND is 0.142 to 0.833. Our result also shows that board meet (BODMEET) 5.484 times in a year, averagely, within the range of 3 to 17 . The mean for ACSIZE is 3.251, with the minimum member of 2 and the maximum member of 5. The typical percentage of independent directors in audit committee (ACIND) is $88.8 \%$. The ACMEET for about 4.986 times in a year. 
Table. 1 Descriptive Statistics

\begin{tabular}{|l|c|c|c|c|c|c|c|}
\hline Variables (n=1400) & Mean & SD & Min & Max & $\mathbf{2 5 \%}$ & $\mathbf{5 0 \%}$ & $\mathbf{7 5 \%}$ \\
\hline DD & 0.07604 & 0.0885 & 0.000725 & 0.51438 & 0.0225 & 0.0493 & 0.0901 \\
\hline MJONES & 0.22548 & 0.43637 & 0.002013 & 2.6534 & 0.0379 & 0.0852 & 0.1717 \\
\hline KOTHARI & 0.27366 & 0.497 & 0.00166 & 3.1948 & 0.0542 & 0.1151 & 0.2365 \\
\hline SP & 0.8242 & 0.3807 & 0 & 1 & 1 & 1 & 1 \\
\hline GENDER & 0.0897 & 0.1109 & 0 & 0.4 & 0 & 0 & 0.1667 \\
\hline NATION & 0.0737 & 0.144 & 0 & 0.71 & 0 & 0 & 0.1 \\
\hline EDULEVEL & 0.5645 & 0.1533 & 0 & 0.958 & 0.4898 & 0.6 & 0.66 \\
\hline EDUBGROUND & 0.7243 & 0.1154 & 0.19 & 0.911 & 0.66 & 0.74 & 0.81 \\
\hline ETHNIC & 0.3843 & 0.191 & 0 & 0.77 & 0.266 & 0.41 & 0.5 \\
\hline AGE & 0.157 & 0.048 & 0.062 & 0.283 & 0.121 & 0.153 & 0.195 \\
\hline TENURE & 0.6048 & 0.3392 & 0 & 1.69 & 0.36 & 0.57 & 0.78 \\
\hline BODSIZE & 7.4635 & 1.865 & 4 & 15 & 6 & 7 & 9 \\
\hline BODIND & 0.458 & 0.128 & 0.142 & 0.833 & 0.375 & 0.428 & 0.555 \\
\hline BODMEET & 5.484 & 1.914 & 3 & 17 & 4 & 5 & 6 \\
\hline ACSIZE & 3.251 & 0.5097 & 2 & 5 & 3 & 3 & 3 \\
\hline ACIND & 0.888 & 0.148 & 0.23 & 1 & 0.75 & 1 & 1 \\
\hline ACMEET & 4.986 & 1.0006 & 4 & 10 & 4 & 5 & 5 \\
\hline SIZE & 19.78 & 1.408 & 14.055 & 24.75 & 18.829 & 19.621 & 20.564 \\
\hline LEV & 0.3591 & 0.242 & 0.0016 & 1.4449 & 0.1864 & 0.333 & 0.4781 \\
\hline PROFIT & 0.0818 & 1.312 & -11.029 & 47.275 & 0.008 & 0.0432 & 0.0835 \\
\hline NCF/LTA & 0.0968 & 1.351 & -0.287 & 50.449 & 0.00073 & 0.0547 & 0.11176 \\
\hline PPE/LTA & 0.5733 & 0.5588 & 0.00057 & 4.016 & 0.1967 & 0.4818 & 0.779 \\
\hline CHGESALES/LTA & 0.0356 & 0.2313 & -0.843 & 0.9172 & -0.0507 & 0.02033 & 0.1104 \\
\hline TA/LTA & 0.1974 & 6.746 & -12.524 & 237.819 & -0.0389 & 0.0136 & 0.0599 \\
\hline BIG4 & 0.57503 & 0.4944 & 0 & 1 & 0 & 1 & 1 \\
\hline LOSS & 0.19 & 0.3924 & 0 & 1 & 0 & 0 & 1 \\
\hline SIZE (RM) & $1.45 \mathrm{e}+09$ & $4.89 \mathrm{e}+09$ & 1271859 & $4.91 \mathrm{e}+10$ & $1.44 \mathrm{e}+08$ & $3.04 \mathrm{e}+08$ & $7.64 \mathrm{e}+08$ \\
\hline & & & & & & & \\
\hline
\end{tabular}

\section{OLS Regression (Seven Years Data - from 2009 until 2015)}

We run OLS Regression using 2009-2015 data and we tabulate our regression findings in Table 2 below. In Model 1 , when we used DD as proxy for earnings management, we found that NATION is significantly and positively related to DD at $p<0.05$. This suggest that NATION increases manager's tendency to manipulate earnings, as measured using DD estimation. In respect to corporate governance variable, we found positive association between BODMEET and $E M$ at $p<0.10$. This indicates that high number of BODMEET is associated with higher EM, as measured using DD. In regards to the control variables related to firmcharacteristics, our result exhibit that negative relationship between SIZE and EM at $p<0.01$, hence suggesting that larger firms are associated with lower EM practices in Malaysia. With respect to the firm-characteristics, SIZE found to be negatively related to EM at $\mathrm{p}<0.01$ (coef= $0.00536, t=-2.70)$. This suggest that large firms manage earnings less. This finding is in line with the view that large firms are under public scrutiny in regards to their financial report, hence this reduce their propensity to manipulate earnings.

When we replace DD with MJONES in Model 2, our result reported that EDULEVEL increases MJONES at $p<0.05$. This finding exhibit that diversity in education level of the board improve managers propensity to manipulate earnings. We also discovered inverse association between
SIZE and EM (as measured using MJONES) in line with our finding in Model 1. Moreover, other corporate characteristics such as PPE/LTA, CHGEINSALES/LTA and TA/LTA reported significant positive relationship with EM at $\mathrm{p}<0.01, \mathrm{p}<0.10$ and $\mathrm{p}<0.05$ respectively. In respect to corporate governance characteristics, we found that BODMEET positively related to EM at $\mathrm{p}<0.10$. This suggest that higher BODMEET is associated with higher EM (as measured using DD). In regards to firm specific characteristics, in line with our findings in Model 1, we found that SIZE negatively related to EM at $\mathrm{p}<0.01$ (coef= 0.04011 ; t-stat $=-3.45)$, while PPE/LTA reported positive association on EM at p<0.01 (coef=0.09195; t-stat=3.49).

In Model 3, we used KOTHARI as a proxy for EM, and consistent with our result in Model 2, our result also demonstrated that EDULEVEL is positively related to EM (as measured using KOTHARI model) at $\mathrm{p}<0.05$. All of our governance variables are insignificant in Model 3. However, we found that CHGEINSALES/LTA, TA/LTA and PPE/LTA are positively related to EM at $p<0.1, p<0.05$ and $\mathrm{p}<0.01$ respectively. Our result in Model 3 also demonstrated that SIZE and LEV are both negatively related to $\mathrm{EM}$ at $\mathrm{p}<0.01(\mathrm{coef}=-0.0519 ; \mathrm{t}-\mathrm{stat}=-3.85)$ and $\mathrm{p}<0.10$ (coef $=-0.0949$, t-stat $=-1.84)$ respectively.

Published By: Blue Eyes Intelligence Engineering 
In Model 4, using managers tendency to report profit rather than a loss (SP) as a proxy for EM, we found that an increase in NATION, EDULEVEL and TENURE enhance

SP at $p<0.05, p<0.01$ and $p<0.05$ respectively. In line with our hypothesis, our result in Model 4 also demonstrated that ETHNIC shows negative relationship with SP at $\mathrm{p}<0.01$. In regards to the corporate governance variables, we found that BODMEET and ACSIZE are negatively related to EM (measured using SP) at $\mathrm{p}<0.05$ and $\mathrm{p}<0.05$ respectively. We also found that ACMEET positively related to EM at $\mathrm{p}<0.05$. This finding indicates that higher number of audit committee meeting increases managers propensity to manipulate earnings. In Model 4, we also found that SIZE and LOSS are both inversely related to EM at $\mathrm{p}<0.05$ (coef= $-0.6503, \mathrm{t}-\mathrm{stat}=-2.25)$ and $\mathrm{p}<0.01(\mathrm{coef}=-11.703, \mathrm{t}-\mathrm{stat}=-$ $8.13)$ respectively.

Table. 2 OLS Regression (2009-2015)

\begin{tabular}{|c|c|c|c|c|}
\hline DV & $\begin{array}{c}\text { DD } \\
\text { (coef) } \\
\text { t-stat }\end{array}$ & $\begin{array}{c}\text { MJ } \\
\text { (coef) } \\
\text { t-stat }\end{array}$ & $\begin{array}{l}\text { KOT } \\
\text { (coef) } \\
\text { t-stat }\end{array}$ & $\begin{array}{c}\text { SP } \\
\text { (coef) } \\
\text { t-stat }\end{array}$ \\
\hline \multicolumn{5}{|l|}{ Diversity Variables } \\
\hline GENDER & $\begin{array}{l}-0.017 \\
(-0.85)\end{array}$ & $\begin{array}{c}0.05448 \\
(0.68)\end{array}$ & $\begin{array}{c}0.15316 \\
(1.48)\end{array}$ & $\begin{array}{l}-0.6685 \\
(-0.32)\end{array}$ \\
\hline NATION & $\begin{array}{c}0.0443 * * \\
(2.53)\end{array}$ & $\begin{array}{c}-0.00622 \\
(-0.08)\end{array}$ & $\begin{array}{c}0.0083 \\
(0.11)\end{array}$ & $\begin{array}{l}3.727 * * \\
(2.52)\end{array}$ \\
\hline EDULEVEL & $\begin{array}{c}0.0132 \\
(0.93)\end{array}$ & $\begin{array}{c}0.1547 * * \\
(2.39)\end{array}$ & $\begin{array}{c}0.179 * * \\
(2.40)\end{array}$ & $\begin{array}{l}3.816 * * * * \\
(3.48)\end{array}$ \\
\hline EDUBGROUND & $\begin{array}{c}0.0167 \\
(0.84)\end{array}$ & $\begin{array}{c}-0.0889 \\
(-0.90)\end{array}$ & $\begin{array}{c}-0.1315 \\
(-1.09)\end{array}$ & $\begin{array}{l}0.17014 \\
(0.07)\end{array}$ \\
\hline ETHNIC & $\begin{array}{c}-0.0232 \\
(-1.49)\end{array}$ & $\begin{array}{c}0.05054 \\
(0.90)\end{array}$ & $\begin{array}{c}0.07004 \\
(1.09)\end{array}$ & $\begin{array}{l}-5.763 * * * * \\
(-4.01)\end{array}$ \\
\hline AGE & $\begin{array}{l}0.067 \\
(1.21) \\
\end{array}$ & $\begin{array}{c}0.2062 \\
(1.02) \\
\end{array}$ & $\begin{array}{l}0.1909 \\
(0.83) \\
\end{array}$ & $\begin{array}{l}-0.262 \\
(-0.06) \\
\end{array}$ \\
\hline TENURE & $\begin{array}{l}0.0099 \\
(1.29) \\
\end{array}$ & $\begin{array}{c}0.00156 \\
(0.05)\end{array}$ & $\begin{array}{l}0.0217 \\
(0.62) \\
\end{array}$ & $\begin{array}{l}1.194 * * * \\
(2.11) \\
\end{array}$ \\
\hline \multicolumn{5}{|c|}{ Corporate Governance Variables } \\
\hline BODSIZE & $\begin{array}{c}-0.001522 \\
(-0.98)\end{array}$ & $\begin{array}{c}0.00333 \\
(0.42)\end{array}$ & $\begin{array}{c}0.000329 \\
(0.04)\end{array}$ & $\begin{array}{l}0.3088 \\
(1.26)\end{array}$ \\
\hline BODIND & $\begin{array}{c}0.0245 \\
(1.04)\end{array}$ & $\begin{array}{l}0.036 \\
(0.38)\end{array}$ & $\begin{array}{c}0.0356 \\
(0.33)\end{array}$ & $\begin{array}{l}-3.683 \\
(-0.87)\end{array}$ \\
\hline BODMEET & $\begin{array}{c}\mathbf{0 . 0 0 3 1 6}^{*} \\
(1.83)\end{array}$ & $\begin{array}{l}0.0008 \\
(0.10)\end{array}$ & $\begin{array}{l}0.005 \\
(0.53)\end{array}$ & $\begin{array}{l}-0.3375 * * \\
(-2.13)\end{array}$ \\
\hline ACSIZE & $\begin{array}{c}0.0023 \\
(0.41)\end{array}$ & $\begin{array}{c}0.01049 \\
(0.40)\end{array}$ & $\begin{array}{c}0.0026 \\
(0.10)\end{array}$ & $\begin{array}{l}-1.1617 * * * \\
(-2.00)\end{array}$ \\
\hline ACIND & $\begin{array}{l}-0.001 \\
(-0.06) \\
\end{array}$ & $\begin{array}{l}0.0263 \\
(0.32)\end{array}$ & $\begin{array}{l}-0.0377 \\
(-0.40) \\
\end{array}$ & $\begin{array}{l}2.2207 \\
(0.98) \\
\end{array}$ \\
\hline ACMEET & $\begin{array}{l}0.0027 \\
(0.94) \\
\end{array}$ & $\begin{array}{c}0.00722 \\
(0.50)\end{array}$ & $\begin{array}{c}0.0246 \\
(1.31) \\
\end{array}$ & $\begin{array}{l}0.468^{* * *} \\
(1.97)\end{array}$ \\
\hline \multicolumn{5}{|l|}{ Control Variables } \\
\hline SIZE & $\begin{array}{c}-0.00536 * * * * \\
(-2.70)\end{array}$ & $\begin{array}{c}-0.04011 * * * * \\
(-3.45)\end{array}$ & $\begin{array}{c}-0.0519 * * * * \\
(-3.85)\end{array}$ & $\begin{array}{l}-0.6503 * * \\
(-2.25)\end{array}$ \\
\hline$\overline{\mathrm{LEV}}$ & $\begin{array}{c}-0.000283 \\
(-0.02)\end{array}$ & $\begin{array}{l}-0.036 \\
(-0.85)\end{array}$ & $\begin{array}{c}-0.0949 * \\
(-1.84)\end{array}$ & $\begin{array}{l}1.741 \\
(1.24)\end{array}$ \\
\hline PROFIT & $\begin{array}{c}-0.0010955 \\
(-0.98)\end{array}$ & $\begin{array}{l}0.0142 \\
(1.19)\end{array}$ & $\begin{array}{l}0.0157 \\
(1.22) \\
\end{array}$ & $\begin{array}{l}0.824 \\
(0.73)\end{array}$ \\
\hline $\mathrm{NCF} / \mathrm{LTA}$ & $\begin{array}{c}0.00324 \\
(1.02)\end{array}$ & $\begin{array}{c}-0.0514 \\
(-0.99)\end{array}$ & $\begin{array}{c}-0.0557 \\
(-0.81)\end{array}$ & $\begin{array}{l}0.3013 \\
(0.77)\end{array}$ \\
\hline PPE/LTA & $\begin{array}{c}0.00436 \\
(0.56)\end{array}$ & $\begin{array}{c}0.09195 * * * \\
(3.49)\end{array}$ & $\begin{array}{c}\text { 0.1414*** } \\
(3.84)\end{array}$ & $\begin{array}{l}-0.08 \\
(-0.14)\end{array}$ \\
\hline CHGESALES/LTA & $\begin{array}{l}0.0105 \\
(0.83)\end{array}$ & $\begin{array}{c}0.0986 * \\
(1.73)\end{array}$ & $\begin{array}{c}0.0761 \\
(1.24)\end{array}$ & $\begin{array}{l}1.0537 \\
(0.82)\end{array}$ \\
\hline TA/LTA & $\begin{array}{c}-0.00105 \\
(-1.63)\end{array}$ & $\begin{array}{c}\mathbf{0 . 0 2 1 6} * * \\
(1.98)\end{array}$ & $\begin{array}{c}0.0238 \\
(1.64)\end{array}$ & $\begin{array}{l}-0.0547 \\
(-0.81) \\
\end{array}$ \\
\hline BIG4 & $\begin{array}{c}0.00406 \\
(0.81) \\
\end{array}$ & $\begin{array}{c}0.03664 \\
(1.65) \\
\end{array}$ & $\begin{array}{l}0.0287 \\
(1.13) \\
\end{array}$ & \\
\hline
\end{tabular}


Diversity of Internal Governance and Financial Reporting Quality: Post-GFC of an Emerging Market

\begin{tabular}{|c|c|c|c|c|}
\hline LOSS & $\begin{array}{c}0.00646 \\
(0.95)\end{array}$ & $\begin{array}{c}-0.0313 \\
(-1.42) \\
\end{array}$ & $\begin{array}{c}-0.0405 \\
(-1.48) \\
\end{array}$ & $\begin{array}{l}-11.703 * * * * \\
(-8.13) \\
\end{array}$ \\
\hline Year dummies & Yes & Yes & Yes & Yes \\
\hline Industries dummies & Yes & Yes & Yes & Yes \\
\hline $\mathrm{N}$ & 1400 & 1400 & 1400 & 1400 \\
\hline R2 & 0.0908 & 0.2411 & 0.2148 & 0.9044 \\
\hline F/ wald chi 2 & 5.40 & 166.82 & 84.26 & 252.10 \\
\hline $\mathrm{p}>\mathrm{F} / \mathrm{chi} 2$ & 0.000 & 0.000 & 0.000 & 0.000 \\
\hline
\end{tabular}

\section{Interaction Term}

In Table 3, we include the interaction terms in all of our baseline model (as in Table 2). We used GENDER as the basis for our interaction because GENDER has been mandated to be one of the requirement for listed firms in Malaysia, where the $30 \%$ minimum quota for BOD position must be allocated to the female. In Model 1, when we used DD as proxy for EM, we found that GENDER*NATION and GENDER*EDULEVEL are both negatively related to $E M$ at $p<0.01$ and $p<0.10$ respectively. This suggest that the GENDER and NATION are complementary each other and the synergy between them are able to reduce EM. Similarly, the interaction between GENDER and EDULEVEL make them complement each other, thus be able to reduce EM. We therefore would like to suggest the optimal diversity mechanism in the firms by maintaining a diverse GENDER, EDULEVEL and NATION in the firms, as to prevent EM in the firms. However, we found that none of our interaction terms are significant in Model $2 \& 3$ when we used MJONES and KOTHARI as proxy for EM. In model 4, when we used SP as proxy for EM, similar to our finding in Model 1, we found that GENDER*EDULEVEL is negatively related to $E M$ at $p<0.10$. This suggest that the complementary interaction between GENDER and EDULEVEL in curbing earnings management practices.

Table 3: OLS Regression with the Interaction Terms

\begin{tabular}{|c|c|c|c|c|}
\hline DV & $\begin{array}{c}\text { DD } \\
\text { (coef) } \\
\text { t-stat }\end{array}$ & $\begin{array}{c}\text { MJ } \\
\text { (coef) } \\
\text { t-stat }\end{array}$ & $\begin{array}{l}\text { KOT } \\
\text { (coef) } \\
\text { t-stat }\end{array}$ & $\begin{array}{c}\text { SP } \\
\text { (coef) } \\
\text { t-stat }\end{array}$ \\
\hline \multicolumn{5}{|l|}{ Interaction Terms } \\
\hline GENDER*NATION & $\begin{array}{c}-0.394 * * * \\
(-2.42)\end{array}$ & $\begin{array}{c}0.0706 \\
(0.12)\end{array}$ & $\begin{array}{l}-0.459 \\
(-0.62)\end{array}$ & $\begin{array}{l}-22.42 \\
(-1.23)\end{array}$ \\
\hline GENDER*EDULEVEL & $\begin{array}{c}-0.2617^{*} \\
(-1.66)\end{array}$ & $\begin{array}{c}0.5815 \\
(1.12)\end{array}$ & $\begin{array}{l}1.018 \\
(1.65)\end{array}$ & $\begin{array}{c}-13.992 * \\
(-1.88)\end{array}$ \\
\hline GENDER*EDUBGROUND & $\begin{array}{c}0.0916 \\
(0.54)\end{array}$ & $\begin{array}{l}1.135 \\
(1.48)\end{array}$ & $\begin{array}{l}1.0302 \\
(1.06)\end{array}$ & $\begin{array}{c}-27.329 \\
(-0.51)\end{array}$ \\
\hline GENDER*ETHNIC & $\begin{array}{l}-0.1659 \\
(-1.15)\end{array}$ & $\begin{array}{l}0.278 \\
(0.68) \\
\end{array}$ & $\begin{array}{l}0.673 \\
(1.39)\end{array}$ & $\begin{array}{l}-17.65 \\
(-1.29)\end{array}$ \\
\hline$G E N D E R * A G E$ & $\begin{array}{l}-0.5262 \\
(-1.36)\end{array}$ & $\begin{array}{l}-1.155 \\
(-0.87)\end{array}$ & $\begin{array}{l}-2.656 \\
(-1.44)\end{array}$ & $\begin{array}{r}-40.671 \\
(-0.97)\end{array}$ \\
\hline GENDER*TENURE & $\begin{array}{c}0.0693 \\
(1.20) \\
\end{array}$ & $\begin{array}{r}-0.1229 \\
(-0.61) \\
\end{array}$ & $\begin{array}{c}-0.0116 \\
(-0.05) \\
\end{array}$ & $\begin{array}{l}3.701 \\
(0.53) \\
\end{array}$ \\
\hline \multicolumn{5}{|l|}{ Diversity Variables } \\
\hline GENDER & $\begin{array}{c}0.1913 \\
(1.45) \\
\end{array}$ & $\begin{array}{c}-0.916 * \\
(-1.83) \\
\end{array}$ & $\begin{array}{c}-0.9177 \\
(-1.29) \\
\end{array}$ & $\begin{array}{c}40.769 \\
(0.93) \\
\end{array}$ \\
\hline NATION & $\begin{array}{c}0.0802 * * * \\
(2.94)\end{array}$ & $\begin{array}{l}-0.006 \\
(-0.06)\end{array}$ & $\begin{array}{c}0.0572 \\
(0.52)\end{array}$ & $\begin{array}{c}5.013 * * * \\
(2.62)\end{array}$ \\
\hline EDULEVEL & $\begin{array}{c}0.03306 \\
(1.62) \\
\end{array}$ & $\begin{array}{c}0.1051 \\
(1.25) \\
\end{array}$ & $\begin{array}{c}0.08439 \\
(0.88) \\
\end{array}$ & $\begin{array}{l}4.577 \\
(3.20) \\
\end{array}$ \\
\hline EDUBGROUND & $\begin{array}{c}0.1059 \\
(0.45)\end{array}$ & $\begin{array}{c}-0.1606 \\
(-1.31)\end{array}$ & $\begin{array}{l}-0.186 \\
(-1.22)\end{array}$ & $\begin{array}{l}0.249 \\
(0.08)\end{array}$ \\
\hline ETHNIC & $\begin{array}{c}-0.00994 \\
(-0.49)\end{array}$ & $\begin{array}{c}0.02256 \\
(0.34)\end{array}$ & $\begin{array}{l}0.004 \\
(0.05)\end{array}$ & $\begin{array}{c}-5.0007 * * * * \\
(-2.64)\end{array}$ \\
\hline $\mathrm{AGE}$ & $\begin{array}{c}0.1099 \\
(1.46)\end{array}$ & $\begin{array}{c}0.3037 \\
(1.33)\end{array}$ & $\begin{array}{c}0.4345 \\
(1.58)\end{array}$ & $\begin{array}{l}2.689 \\
(0.52)\end{array}$ \\
\hline TENURE & $\begin{array}{c}0.0056 \\
(0.51) \\
\end{array}$ & $\begin{array}{c}0.0089 \\
(0.22) \\
\end{array}$ & $\begin{array}{c}0.0137 \\
(0.32) \\
\end{array}$ & $1.0588 *$ \\
\hline
\end{tabular}


International Journal of Recent Technology and Engineering (IJRTE) ISSN: 2277-3878, Volume-8, Issue-2S2, July 2019

\begin{tabular}{|c|c|c|c|c|}
\hline Corporate Governance Variables & & & & \\
\hline BODSIZE & $\begin{array}{c}-0.00138 \\
(-0.87) \\
\end{array}$ & $\begin{array}{c}0.0038 \\
(0.47)\end{array}$ & $\begin{array}{c}0.0013 \\
(0.14)\end{array}$ & $\begin{array}{l}0.369 \\
(1.36) \\
\end{array}$ \\
\hline BODIND & $\begin{array}{c}0.0255 \\
(1.07)\end{array}$ & $\begin{array}{c}0.0442 \\
(0.47)\end{array}$ & $\begin{array}{c}0.0563 \\
(0.51)\end{array}$ & $\begin{array}{l}-2.831 \\
(-0.65)\end{array}$ \\
\hline BODMEET & $\begin{array}{c}0.00277 \\
(1.63)\end{array}$ & $\begin{array}{c}0.00083 \\
(0.09)\end{array}$ & $\begin{array}{c}0.0054 \\
(0.55)\end{array}$ & $\begin{array}{c}-0.379 * * \\
(-2.29)\end{array}$ \\
\hline ACSIZE & $\begin{array}{c}0.00261 \\
(0.46)\end{array}$ & $\begin{array}{c}0.00887 \\
(0.34) \\
\end{array}$ & $\begin{array}{c}-0.00009 \\
(-0.00) \\
\end{array}$ & $\begin{array}{c}-1.292 * \\
(-1.96) \\
\end{array}$ \\
\hline ACIND & $\begin{array}{c}0.0028 \\
(0.16)\end{array}$ & $\begin{array}{c}0.0227 \\
(0.28)\end{array}$ & $\begin{array}{l}-0.050 \\
(-0.54)\end{array}$ & $\begin{array}{l}2.502 \\
(0.99)\end{array}$ \\
\hline ACMEET & $\begin{array}{c}0.00266 \\
(0.92)\end{array}$ & $\begin{array}{c}0.00756 \\
(0.28)\end{array}$ & $\begin{array}{l}0.025 \\
(1.34) \\
\end{array}$ & $\begin{array}{c}0.42002 \\
(1.51)\end{array}$ \\
\hline \multicolumn{5}{|l|}{ Control Variables } \\
\hline SIZE & $\begin{array}{c}-0.0057 * * * \\
(-2.83)\end{array}$ & $\begin{array}{c}-0.0406^{* * * *} \\
(-3.40)\end{array}$ & $\begin{array}{c}-0.0535 * * * \\
(-3.86)\end{array}$ & $\begin{array}{c}-0.6302 * * \\
(-2.31)\end{array}$ \\
\hline LEV & $\begin{array}{c}0.00163 \\
(0.14) \\
\end{array}$ & $\begin{array}{c}-0.0402 \\
(-0.92) \\
\end{array}$ & $\begin{array}{r}-0.0997 \\
(-1.91) \\
\end{array}$ & $\begin{array}{c}1.9509 \\
(1.19) \\
\end{array}$ \\
\hline PROFIT & $\begin{array}{c}-0.000955 \\
(-0.88)\end{array}$ & $\begin{array}{c}0.0143 \\
(1.20)\end{array}$ & $\begin{array}{c}0.0156 \\
(1.20)\end{array}$ & $\begin{array}{c}0.5414 \\
(0.57)\end{array}$ \\
\hline NCF/LTA & $\begin{array}{c}0.0041 \\
(1.29)\end{array}$ & $\begin{array}{c}-0.0532 \\
(-1.03)\end{array}$ & $\begin{array}{l}-0.057 \\
(-0.84)\end{array}$ & $\begin{array}{c}0.4663 \\
(0.80)\end{array}$ \\
\hline PPE/LTA & $\begin{array}{c}0.00355 \\
(0.47) \\
\end{array}$ & $\begin{array}{c}0.09168 * * * \\
(3.51) \\
\end{array}$ & $\begin{array}{c}0.1416 * * * \\
(3.86) \\
\end{array}$ & $\begin{array}{c}-0.1443 \\
(-0.26) \\
\end{array}$ \\
\hline CHGESALES/LTA & $\begin{array}{c}0.0085 \\
(0.68)\end{array}$ & $\begin{array}{c}0.10199 * \\
(1.78)\end{array}$ & $\begin{array}{c}0.0825 \\
(1.32)\end{array}$ & $\begin{array}{c}0.8004 \\
(0.51)\end{array}$ \\
\hline TA/LTA & $\begin{array}{c}-0.00128 * * \\
(-2.00) \\
\end{array}$ & $\begin{array}{c}0.02212 * * \\
(2.03) \\
\end{array}$ & $\begin{array}{c}0.0241 * \\
(1.69) \\
\end{array}$ & $\begin{array}{l}-0.926 \\
(-0.83) \\
\end{array}$ \\
\hline BIG4 & $\begin{array}{c}0.0061 \\
(1.22)\end{array}$ & $\begin{array}{c}0.0345 \\
(1.55) \\
\end{array}$ & $\begin{array}{c}0.0269 \\
(1.05)\end{array}$ & $\begin{array}{c}1.361 * * \\
(2.03)\end{array}$ \\
\hline LOSS & $\begin{array}{l}0.007 \\
(1.06)\end{array}$ & $\begin{array}{c}-0.0336 \\
(-1.51)\end{array}$ & $\begin{array}{l}-0.043 \\
(-1.58)\end{array}$ & $\begin{array}{c}-12.107 * * * \\
(-6.22)\end{array}$ \\
\hline Year dummies & Yes & Yes & Yes & Yes \\
\hline Industries dummies & Yes & Yes & Yes & Yes \\
\hline $\mathrm{N}$ & 1400 & 1400 & 1400 & 1400 \\
\hline $\mathrm{R} 2$ & 0.10 & 0.2433 & 0.2222 & 0.9073 \\
\hline F/ wald chi2 & 5.07 & 145.43 & 74.10 & 249.23 \\
\hline $\mathrm{p}>\mathrm{F} / \mathrm{chi} 2$ & 0.00 & 0.000 & 0.000 & 0.000 \\
\hline
\end{tabular}

\section{OLS Regression - Yearly Analysis}

The regression analysis in a yearly basis that is from 2009-2015 signifies that the results are varies between year to year. We simplify the results (for diversity variables only) in the Table 4 below. As we can see from Table 4, we found that GENDER is positive to EM as recorded in the year 2009 (Model 2 \& 3) and 2010 (Model 4) results. This suggest that gender diversity increases earnings management. In regards to ETHNIC, we found consistent evident that ETHNIC is negatively related to EM as reported in Model 4 in the year 2009, 2010 and 2015.

NATION however shows mixed results, where in the year 2009 (Model 4) and 2014 (Model 1 \& 3) documented a significant positive link with EM, while in the year 2015, Model 2 reported a significant negative link between NATION and EM. In regards to EDULEVEL, we found that an increase in EDULEVEL enhance EM in Model 4 in the year 2010 and 2015 at $p<0.1$ and $p<0.05$ respectively. TENURE also reported mixed result where it exhibit negative association to EM in Model 2 in the year 2012 and Model 4 in the year 2014. Nevertheless, our result also demonstrated positive link between TENURE and EM in Model 1 in the year 2012.

In regards to AGE, we found that AGE negatively related to EM in 2014 (Model 3) and 2015 (Model 4). Nevertheless, in Model 4 during the year 2014, we found AGE to be positively related to EM. Overall, we found that TENURE, AGE and NATION reported mixed results in the yearly basis regression analysis. GENDER however consistently reported positive result to EM while ETHNIC constantly reported negative association to EM. 
Table.4 Summary of the yearly regression analyses for the year 2009-2015

\begin{tabular}{|c|c|c|c|c|}
\hline DependentVariables/Year & DDModel 1 & $\begin{array}{l}\text { MJONESModel } \\
2\end{array}$ & KOTHARIModel 3 & SPModel 4 \\
\hline 2009 & Nil & Gender $(+) *$ & Gender $(+)^{*}$ & $\begin{array}{c}\text { Nation (+) } * * * \\
\text { Ethnic (-) } * *\end{array}$ \\
\hline 2010 & Nil & Nil & Nil & $\begin{array}{c}\text { Gender (+) ** } \\
\text { Edulevel (+) * } \\
\text { Ethnic (-)* }\end{array}$ \\
\hline 2011 & Nil & $\mathrm{Nil}$ & Nil & Gender (+) ** \\
\hline 2012 & Tenure $(+) * *$ & Tenure (-) ** & Nil & Nil \\
\hline 2013 & Nil & Nil & Nil & Nil \\
\hline 2014 & Nation $(+) * * *$ & Nil & $\begin{array}{c}\text { Nation (+)* } \\
\text { Age (-) * }\end{array}$ & $\begin{array}{c}\text { Age (+)* } \\
\text { Tenure (-)** }\end{array}$ \\
\hline 2015 & Nil & Nation (-) * & Nil & $\begin{array}{c}\text { Edulevel (+) } * * \\
\text { Ethnic (-) } * * \\
\operatorname{Age}(-) * *\end{array}$ \\
\hline
\end{tabular}

\section{Analysis for Post-GFC (2009-2011)}

We split the sample into post-GFC dataset that is during 2009-2011 as we intend to see the impact of board diversity on earnings management after the economic turmoil. We tabulate the result in Table 5 above. Using post-GFC dataset, we found that in Model 4, GENDER is negatively related to EM at $\mathrm{p}<0.10$, while NATION and TENURE are positively related to EM at $\mathrm{p}<0.05$ and $\mathrm{p}<0.05$ respectively. This suggest that the role of GENDER is effective to mitigate EM (related to the tendency to report a profit rather than a loss) during post-GFC period.

Model 3 however reported that GENDER shows positive association to $\mathrm{EM}$ at $\mathrm{p}<0.10$, which is contradict to our finding in Model 4.

Table. 5 OLS Regression using Post-GFC dataset (2009-2011)

\begin{tabular}{|c|c|c|c|c|}
\hline DV & $\begin{array}{c}\text { DD } \\
\text { (coef) } \\
\text { t-stat }\end{array}$ & $\begin{array}{c}\text { MJ } \\
\text { (coef) } \\
\text { t-stat }\end{array}$ & $\begin{array}{c}\text { KOT } \\
\text { (coef) } \\
\text { t-stat }\end{array}$ & $\begin{array}{c}\text { SP } \\
\text { (coef) } \\
\text { t-stat }\end{array}$ \\
\hline \multicolumn{5}{|c|}{ Diversity Variables } \\
\hline GENDER & $\begin{array}{c}-0.0275 \\
(-0.86)\end{array}$ & $\begin{array}{c}0.1166 \\
(0.81)\end{array}$ & $\begin{array}{c}0.2808^{*} \\
(1.69)\end{array}$ & $\begin{array}{c}-18.026 * \\
(-1.84)\end{array}$ \\
\hline NATION & $\begin{array}{c}0.03085 \\
(1.16)\end{array}$ & $\begin{array}{c}0.07502 \\
(0.55)\end{array}$ & $\begin{array}{c}0.0213 \\
(0.16)\end{array}$ & $\begin{array}{c}15.098 * * \\
(2.36)\end{array}$ \\
\hline EDULEVEL & $\begin{array}{c}0.0171 \\
(0.81)\end{array}$ & $\begin{array}{c}0.1577 \\
(1.64)\end{array}$ & $\begin{array}{c}0.1528 \\
(1.59)\end{array}$ & $\begin{array}{c}23.508 \\
(1.40)\end{array}$ \\
\hline EDUBGROUND & $\begin{array}{c}0.04714 \\
(1.41) \\
\end{array}$ & $\begin{array}{c}-0.1085 \\
(-0.70) \\
\end{array}$ & $\begin{array}{c}-0.1545 \\
(-0.95)\end{array}$ & $\begin{array}{c}-26.2202 \\
(-1.41)\end{array}$ \\
\hline ETHNIC & $\begin{array}{c}-0.0242 \\
(-0.95)\end{array}$ & $\begin{array}{c}0.04044 \\
(0.45)\end{array}$ & $\begin{array}{c}0.06447 \\
(0.69)\end{array}$ & $\begin{array}{c}-35.562 \\
(-1.60)\end{array}$ \\
\hline $\mathrm{AGE}$ & $\begin{array}{c}0.1451 \\
(1.41)\end{array}$ & $\begin{array}{c}-0.0369 \\
(-0.12)\end{array}$ & $\begin{array}{c}-0.2294 \\
(-0.72)\end{array}$ & $\begin{array}{l}77.99 \\
(1.55)\end{array}$ \\
\hline TENURE & $\begin{array}{l}-0.0058 \\
(-0.55)\end{array}$ & $\begin{array}{c}0.0173 \\
(0.35)\end{array}$ & $\begin{array}{c}0.0538 \\
(1.06)\end{array}$ & $\begin{array}{c}9.418 * * \\
(2.18)\end{array}$ \\
\hline \multicolumn{5}{|c|}{ Corporate Governance Variables } \\
\hline BODSIZE & $\begin{array}{c}-0.000738 \\
(-0.33) \\
\end{array}$ & $\begin{array}{c}0.0223 * \\
(1.73)\end{array}$ & $\begin{array}{c}0.02227 * \\
(1.70) \\
\end{array}$ & $\begin{array}{c}5.423 * \\
(1.67) \\
\end{array}$ \\
\hline BODIND & $\begin{array}{c}0.0122 \\
(0.31)\end{array}$ & $\begin{array}{c}0.0429 \\
(0.29)\end{array}$ & $\begin{array}{c}0.0612 \\
(0.39)\end{array}$ & $\begin{array}{c}-13.921 * * \\
(-2.33)\end{array}$ \\
\hline BODMEET & $\begin{array}{c}-0.000397 \\
(-0.13)\end{array}$ & $\begin{array}{c}0.02188 \\
(1.57)\end{array}$ & $\begin{array}{c}0.02938 * * \\
(2.06)\end{array}$ & $\begin{array}{c}0.0758 \\
(0.21)\end{array}$ \\
\hline ACSIZE & $\begin{array}{c}0.0125 \\
(1.44)\end{array}$ & $\begin{array}{c}-0.0033 \\
(-0.08)\end{array}$ & $\begin{array}{c}-0.0204 \\
(-0.50)\end{array}$ & $\begin{array}{l}-4.655 \\
(-1.38)\end{array}$ \\
\hline ACIND & $\begin{array}{c}0.0174 \\
(0.65)\end{array}$ & $\begin{array}{c}-0.0425 \\
(-0.34)\end{array}$ & $\begin{array}{c}-0.1246 \\
(-0.90)\end{array}$ & $\begin{array}{l}48.84 \\
(1.59)\end{array}$ \\
\hline ACMEET & $\begin{array}{c}0.00619 \\
(1.17)\end{array}$ & $\begin{array}{c}0.0173 \\
(0.71)\end{array}$ & $\begin{array}{c}0.0423 \\
(1.51)\end{array}$ & $\begin{array}{l}0.657 \\
(1.21)\end{array}$ \\
\hline
\end{tabular}




\begin{tabular}{|c|c|c|c|c|}
\hline \multicolumn{5}{|l|}{ Control Variables } \\
\hline SIZE & $\begin{array}{l}-0.0047 \\
(-1.57)\end{array}$ & $\begin{array}{c}-0.0613 \text { **** } \\
(-3.43)\end{array}$ & $\begin{array}{c}-0.0774 * * * * \\
(-4.23)\end{array}$ & $\begin{array}{c}-7.347^{*} \\
(-1.69)\end{array}$ \\
\hline LEV & $\begin{array}{c}0.01038 \\
(0.59)\end{array}$ & $\begin{array}{c}-0.0722 \\
(-1.32)\end{array}$ & $\begin{array}{c}-0.0778 \\
(-1.31)\end{array}$ & $\begin{array}{l}1.163 \\
(0.64)\end{array}$ \\
\hline PROFIT & $\begin{array}{c}-0.000038 \\
(-0.05)\end{array}$ & $\begin{array}{c}0.00539 \\
(1.26)\end{array}$ & $\begin{array}{c}0.00096 \\
(0.19)\end{array}$ & $\begin{array}{c}0.145^{* * *} \\
(2.22)\end{array}$ \\
\hline NCF/LTA & $\begin{array}{c}0.01647 \\
(0.40)\end{array}$ & $\begin{array}{l}0.1605 \\
(0.72)\end{array}$ & $\begin{array}{c}0.1088 \\
(0.47)\end{array}$ & $\begin{array}{l}-5.874 \\
(-1.60)\end{array}$ \\
\hline PPE/LTA & $\begin{array}{c}-0.01646 \\
(-2.69)\end{array}$ & $\begin{array}{c}0.1894 * * * \\
(3.88)\end{array}$ & $\begin{array}{c}0.2857 * * * \\
(5.96)\end{array}$ & $\begin{array}{l}-3.697 \\
(-1.45)\end{array}$ \\
\hline CHGESALES/LTA & $\begin{array}{c}0.00217 \\
(0.10)\end{array}$ & $\begin{array}{c}0.0144 \\
(0.20)\end{array}$ & $\begin{array}{c}-0.0548 \\
(-0.73)\end{array}$ & $\begin{array}{l}2.887 \\
(0.52)\end{array}$ \\
\hline TA/LTA & $\begin{array}{c}-0.000801 \\
(-1.33)\end{array}$ & $\begin{array}{c}0.0204 * * * * \\
(3.66)\end{array}$ & $\begin{array}{c}0.0236 * * * * \\
(2.97)\end{array}$ & $\begin{array}{l}2.701 \\
(0.37)\end{array}$ \\
\hline BIG4 & $\begin{array}{c}0.0059 \\
(0.72)\end{array}$ & $\begin{array}{c}0.0397 \\
(1.21)\end{array}$ & $\begin{array}{c}0.0323 \\
(0.95)\end{array}$ & $\begin{array}{l}5.077 * \\
(1.74)\end{array}$ \\
\hline LOSS & $\begin{array}{c}0.0084 \\
(0.71)\end{array}$ & $\begin{array}{c}-0.0315 \\
(-0.92)\end{array}$ & $\begin{array}{c}-0.0294 \\
(-0.82)\end{array}$ & $\begin{array}{l}-56.51 * \\
(-1.76)\end{array}$ \\
\hline CONS & $\begin{array}{c}0.0106 \\
(0.13)\end{array}$ & $\begin{array}{c}1.6738^{* * * *} \\
(4.15)\end{array}$ & $\begin{array}{c}1.9469 * * * \\
(5.05)\end{array}$ & $\begin{array}{c}115.23 * \\
(1.70)\end{array}$ \\
\hline Year dummies & Yes & Yes & Yes & Yes \\
\hline Industries dummies & Yes & Yes & Yes & Yes \\
\hline $\mathrm{N}$ & 600 & 600 & 600 & 600 \\
\hline R2 & 0.1167 & 0.5415 & 0.5443 & 0.9602 \\
\hline F/ wald chi2 & 4.17 & 106.77 & 18.60 & 108.85 \\
\hline $\mathrm{p}>\mathrm{F} / \mathrm{chi} 2$ & 0.000 & 0.000 & 0.000 & 0.000 \\
\hline
\end{tabular}

\section{CONCLUSION}

We investigate the impact of diverse board on earnings management. We cover seven aspects of diversity including gender, ethnicity, education level, education background, age, tenure and nationality. Using various proxies for earnings management, 1400 firm-year observations over nine years (i.e. from 2009-2015) our findings demonstrated mixed results. We therefore suggest that diversity of board does not really work well in reducing earnings management in Malaysian landscape. While diverse board seems to be fit in reducing managers' opportunistic behaviour in the west, such claim however does not fit to the eastern context. We urge the regulator in eastern country to be more sensitive on the institutional aspect of their own country before adopting any regulations from the west.

\section{ACKNOWLEDGEMENT}

This research is supported by the Research Management Centre (RMIC) of the UniversitiPendidikan Sultan Idris (UPSI) under the University Research Grant (GPU) Scheme (Code: 2016-0144-106-01).

\section{REFERENCE}

1. Abdullah, S. N., Ismail, K. N. I. K., \&Nachum, L. (2016). Does having women on boards create value? The impact of societal perceptions and corporate governance in emerging markets. Strategic Management Journal, 51(37), 466-476. https://doi.org/10.1002/smj

2. Adams, R. B., \& Ferreira, D. (2009). Women in the boardroom and their impact on governance and performance 2 . Journal of Financial Economics, 94(2), https://doi.org/10.1016/j.jfineco.2008.10.007

291-309.
3. Aina, K. (2013). Board of directors and corporate governance in International Journal of Business and Finance Management Research, 1(October 2012), 21-34.

4. Alvarado, N. R., Briones, J. L., \& de Fuentes Ruiz, P. (2011). Gender diversity on Boards of Directors and business success. Investment Management and Financial Innovations, 8(1), 199-209.

5. Anila, K. (2014). Association between gender diversity in board composition and firm performance: Empirical evidence from Finland. University of Oulu.

6. Ansari, S., \& Munir, K. (2008). How valuable is a piece of the spectrum? Determination of value in external resource acquisition. Industrial and Corporate Change, 2, 301-333. https://doi.org/10.1093/icc/dtn004

7. Ararat, M., Aksu, M., \& Cetin, A. T. (2010). Impact of Board Diversity on Boards ' Monitoring Intensity and Firm Performance: Evidence from the Istanbul Stock Exchange. SSRN Electronic Journal, 90(216).

8. Arun, T. G., Almahrog, Y. E., \& Ali Aribi, Z. (2015a). Female directors and earnings management: Evidence from UK companies. International Review of Financial Analysis, 39(May), 137-146. https://doi.org/10.1016/j.irfa.2015.03.002

9. Arun, T. G., Almahrog, Y. E., \& Ali Aribi, Z. (2015b). Female directors and earnings management: Evidence from UK companies. International Review of Financial Analysis, 39, 137-146. https://doi.org/10.1016/j.irfa.2015.03.002

10. Barney, J. B. (2001). Resource-based theories of competitive advantage: A ten-year retrospective on the resource-based view. $\begin{array}{llll}\text { Journal of 27(6), } & \text { 643-650. }\end{array}$ https://doi.org/10.1177/014920630102700602

11. Bathula, H. (2008). Board Characteristics and Firm Performance: Evidence from New Zealand. AUT University New Zealand.

12. Bear, S., Rahman, N., \& Post, C. (2010). The Impact of Board Diversity and Gender Composition on Corporate Social Responsibility and Firm Reputation. Journal of Business Ethics, 97(2), 207-221. https://doi.org/10.1007/s10551-010-0505-2.

13. Ben-Amar, W., Chang, M., \&McIlkenny, P. (2015). Board Gender Diversity and Corporate Response to Sustainability Initiatives Evidence from the Carbon Disclosure Project. Journal of Business

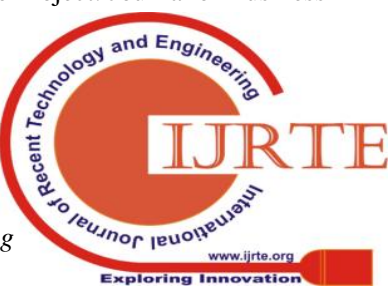


Ethics, 125(3), 497-512. https://doi.org/10.1007/s10551-015-2759-1

14. Boulouta, I. (2013). Hidden Connections: The Link Between Board Gender Diversity and Corporate Social Performance. Journal of Business Ethics, 113(2), 185-197. https://doi.org/10.1007/s10551-0121293-7

15. Bowman, C., \&Ambrosini, V. (2003). What does value mean and how is it created, maintained and destroyed? In Academy of Management Annual Meeting (pp. 1-6). Seattle, Washington.

16. Carter, D., D’Souza, F., Simkins, B. J., \& Simpson, W. G. (2010). The Gender and Ethnic Diversity of US Boards and Board Committees and Firm Financial Performance. Corporate Governance: An International Review, 18(5), 396-414. https://doi.org/10.1111/j.14678683.2010.00809.x

17. Cormier, D., \& Martinez, I. (2006). The association between management earnings forecasts, earnings management, and stock market valuation: Evidence from French IPOs. The International Journal of Accounting, 41(3), 209-236. https://doi.org/10.1016/j.intacc.2006.07.004

18. Dauth, T., Pronobis, P., \&Schmid, S. (2017). Exploring the link between internationalization of top management and accounting quality: The CFO's international experience matters. International Business Review, 26(1), 71-88. https://doi.org/10.1016/j.ibusrev.2016.05.007

19. Dechow, P. M., \&Schrand, C. M. (2004). Earnings Quality. The Research Foundation of CFA Institute.

20. Duong, L., \& Evans, J. (2016). Gender differences in compensation and earnings management: Evidence from Australian CFOs. Pacific-

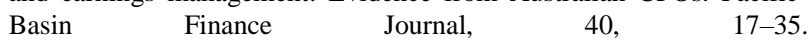
https://doi.org/10.1016/j.pacfin.2016.07.004

21. Duztas, S. (2008). Corporate governance: The effects of board characteristics, information technology maturity and tranparency on company performance. Yeditepe University.

22. Farag, H., \&Mallin, C. (2017). Board diversity and financial fragility: Evidence from European banks. International Review of Financial Analysis, 49 ,

98-112. https://doi.org/http://dx.doi.org/10.1016/j.irfa.2016.12.002

23. Fauzi, F., \& Locke, S. (2012). Board structure, ownership structure and firm performance: a study of New Zealand listed-firms. Asian Academy of Management Journal of Accounting and Finance, (1976).

24. Goergen, M., Limbach, P., \&Scholz, M. (2015). Mind the gap: The age dissimilarity between the chair and the CEO. Journal of Corporate Finance, 35, 136-158. https://doi.org/10.1016/j.jcorpfin.2015.08.011

25. Gul, F. a., \& Leung, S. (2004). Board leadership, outside directors' expertise and voluntary corporate disclosures. Journal of Accounting and Public Policy, 23(5), 351-379. https://doi.org/10.1016/j.jaccpubpol.2004.07.001

26. Gul, F. A., Munir, S., \& Zhang, L. (2016). Ethnicity, politics and firm performance: Evidence from Malaysia. Pacific-Basin Finance Journal, 40, 115-129. https://doi.org/10.1016/j.pacfin.2016.10.005

27. Hafsi, T., \&Turgut, G. (2013). Boardroom Diversity and its Effect on Social Performance: Conceptualization and Empirical Evidence. Journal of Business Ethics, 112, 463-479. https://doi.org/10.1007/s10551-012-1272-z

28. Hahn, P. D., \&Lasfer, M. (2016). Impact of foreign directors on board meeting frequency. International Review of Financial Analysis, 46, 295-308. https://doi.org/10.1016/j.irfa.2015.11.004

29. Hambrick, D. C., \& Mason, P. A. (1984). Upper echelons: The organization as a refection of its top managers. The Academy of Management Review, 9(2), 193-206.

30. Haniffa, R. M., \& Cooke, T. E. (2005). The impact of culture and governance on corporate social reporting. Journal of Accounting and Public Policy, 24(5), 391-430. https://doi.org/10.1016/j.jaccpubpol.2005.06.001

31. Hasnan, S., Rahman, R. A., \&Mahenthiran, S. (2013). Management Motive, Weak Governance, Earnings Management, and Fraudulent Financial Reporting: Malaysian Evidence. Journal of International Accounting Research, 12(1), 1-27. https://doi.org/10.2308/jiar-50353

32. Holm, C., \&Scholer, F. (2010). Reduction of asymmteric information through corporate governance mechanism - the importance of ownership dispersion and exposure toward the international capital market. Corporate Governance: An International Review, 18(1), 32-47.

33. Husillos, J., \& Alvarez, M. (2008). A stakeholder-theory approach to environmental disclosures by small and medium enterprises ( smes ). RC-SAR, 11(1), 125-156.

34. Jensen, C., \&Meckling, H. (1976). Theory of the firm: managerial behaviour, agency costs and ownership structure. Journal of Financial Economics, 3, 305-360.

35. Knyazeva, A., Knyazeva, D., \&Masulis, R. D. (2013). The supply of corporate directors and board independence. Review of Financial Studies, 26, 1561-1605.

36. Krishnan, G. V., \& Parsons, L. M. (2008). Getting to the bottom line: An exploration of gender and earnings quality. Journal of Business Ethics, 78(1-2), 65-76. https://doi.org/10.1007/s10551-006-9314-z

37. La Porta, R., Lopez de Silanes, F., Shleifer, A., \&Vishny, R. W. (2000). Investor Protection and Corporate Governance. Journal of Financial Economics, 58(March), 3-27. https://doi.org/10.2139/ssrn.183908

38. Labelle, R., Gargouri, R. M., \&Francoeur, C. (2010). Ethics, Diversity Management, and Financial Reporting Quality. Journal of Business Ethics, 93(2), 335-353. https://doi.org/10.1007/s10551-009-0225-7

39. Lazzaretti, K., Godoi, C. K., Camilo, S. P. O., \&Marcon, R. (2013). Gender diversity in the boards of directors of Brazilian businesses. Gender in Management: An International Journal, 28(2), 94-110. https://doi.org/10.1108/17542411311303239

40. Luo, J., Xiang, Y., \& Huang, Z. (2017). Female directors and real activities manipulation: Evidence from China. China Journal of Accounting Research. https://doi.org/10.1016/j.cjar.2016.12.004

41. Man, C., \& Wong, B. (2013). Corproate Governance And Earnings Management: A survey of literature. The Journal of Applied Business Research, 29(2), 391-418.

42. Mathisen, G. E., Ogaard, T., \&Marnburg, E. (2012). Women in the Boardroom: How Do Female Directors of Corporate Boards Perceive Boardroom Dynamics? Journal of Business Ethics, 116(1), 87-97. https://doi.org/10.1007/s10551-012-1461-9

43. Miletkov, M., Poulsen, A., \&Wintoki, M. B. (2014). A multinational study of foreign directors on non-US corporate boards. SSRN Electronic Journal.

44. Muttakin, M. B., Khan, A., \&Subramaniam, N. (2015). Firm characteristics, board diversity and corporate social responsibility Evidence from Bangladesh. Pacific Accounting Review, 27(3), 53-372.

45. Pappas, K., Leventis, S., \&Owusu-Ansah, S. (2011). Earnings Management and Corruption: Evidence from the European Union.

46. Peni, E., \&Vähämaa, S. (2010). Female executives and earnings management. Managerial Finance, 36(7), 629-645. https://doi.org/10.1108/03074351011050343

47. Pfeffer, J., \&Salancik, G. R. (1978). The external control of organizations: A resource dependence perspective. Stanford, CA: Stanford Business Books.

48. Post, C., Rahman, N., \&Rubow, E. (2011). Green Governance: Boards of Directors' Composition and Environmental Corporate Social Responsibility. Business \& Society, 50(1), 189-223. https://doi.org/10.1177/0007650310394642

49. Prihatiningtias, Y. W. (2012). Gender diveristy in the boardroom and firm performance: evidience from Indonesian publicly listed financial firms. University of Canberra.

50. Santoso, R. D., \&Rakhman, F. (2013). CEO Characteristics and Earnings Management. The Indonesian Journal of Accounting Research, 16(3), 181-196.

51. Srinidhi, B., Gul, F. a., \&Tsui, J. (2011). Female Directors and Earnings Quality*. Contemporary Accounting Research, 28(5), 16101644. https://doi.org/10.1111/j.1911-3846.2011.01071.x

52. Sun, J., Liu, G., \&Lan, G. (2010). Does Female Directorship on Independent Audit Committees Constrain Earnings Management? Journal of Business Ethics, 99(3), 369-382. https://doi.org/10.1007/s10551-010-0657-0

53. Transparency International. (2015). Corruption perception index 2015. Retrieved from http://www.transparency.org/cpi2015

54. Troy, C., Smith, K. G., \& Domino, M. a. (2011). CEO demographics and accounting fraud: Who is more likely to rationalize illegal acts? $\begin{array}{lll}\text { Strategic } & \text { Organization, } & 9(4),\end{array}$ https://doi.org/10.1177/1476127011421534

55. Wernerfelt, B. (1984). A Resource-based View of the Firm. Strategic Management Journal, 5, 171-180.

56. World Bank. (2016). GINI index (World bank estimate). Retrieved from http://data.worldbank.org/indicator/SI.POV.GINI?order=wb api_data_value_2012+wbapi_data_value\%26sort=asc 